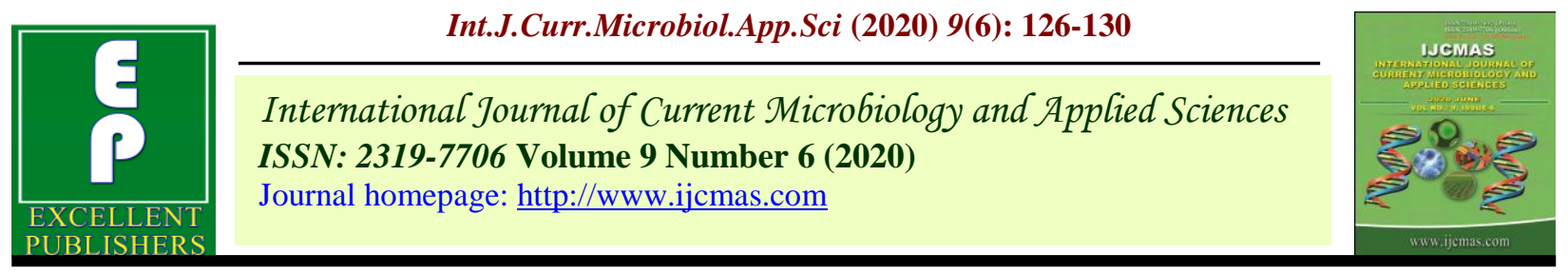

Original Research Article

https://doi.org/10.20546/ijcmas.2020.906.016

\title{
Response of Soybean (Glycine max L. Merril) to Biofertilizer and FYM in the Jhum Fields under Zunheboto Districts of Nagaland, India
}

\author{
Sentimenla* \\ Subject Matter Specialist (Soil Science), \\ KVK : Nagaland University, Lumami-798627, Nagaland, India \\ *Corresponding author
}

\section{A B S T R A C T}

Keywords

Biofertilizer, PSB,

FYM, Jhum and

$\mathrm{B}: \mathrm{C}$ ratio

Article Info

Accepted:

12 May 2020

Available Online:

10 June 2020
This field level demonstration was undertaken to evaluate the response of biofertilizer rhizobium, PSB and FYM in soybean in the jhum fields of zunheboto district, Nagaland. Altogether 3 villages were selected comprising of 9 demonstrations area. The soils were found to have slightly acidic $\mathrm{pH}$ in reaction ranging from 6.0- 6.4, organic carbon ranged from low to medium between $0.27-0.63 \%$, low available nitrogen ranging between $229-249 \mathrm{~kg} \mathrm{ha}^{-1}$, low available phosphorus varied between 8.89 $15.21 \mathrm{~kg} \mathrm{ha-}{ }^{1}$, medium in available potassium ranging from 167.23-227.81 $\mathrm{kg} \mathrm{ha}{ }^{-1}$. From the demonstrations carried out, it was observed that this technology intervention increased the yield, net return, B:C ratio and available NPK of the soil after harvest as compared to traditional farmers.

\section{Introduction}

Soybean is an important legume crop widely used as an oilseed crop. It is known as the golden bean of the twentieth century. It possess high nutritional value containing 20\% oil and $40 \%$ protein. Soybean covers an area of 11.3 million hectares which contributes 0.96 metric tons per hectare (USDA, 2019). In India it is cultivated at an area of 10.69 million ha with a total production of 12.67 million tonnes and productivity $1185 \mathrm{~kg} \mathrm{ha}^{-1}$ respectively (Anonymous, 2013) consisting of
Himachal Pradesh, Uttar Pradesh Bengal, the Khasi Hills, Manipur, the Naga Hills and parts of central India covering Madhya Pradesh. Being a legume crop, it has the ability to fix atmospheric nitrogen and enhances the soil fertility and soil health.

Biofertilizer rhizobium is used in legume crops to enhance soil health and fertility and also to increase the productivity of the crop. It fixes atmospheric nitrogen in the soil and makes it directly available to the plants. They also increase the phosphorous content in the 
soil through solubilisation and releasing unavailable phosphorous into available form in acidic soils where fixation of nutrients occur. It contributes to about $90 \times 106$ metric tons of $\mathrm{N}$ year ${ }^{-1}$ all over the world (Subba Rao, 1982). It is eco-friendly, cost effective and economical to be used by farmers. Rhizobium fixes about $100-300 \mathrm{~kg} \mathrm{~N} /$ ha which meets $80 \% \mathrm{~N}$ and increases soybean production by 10-25\% (Herliana et al., 2015).

Among the means available to achieve sustainability in agricultural production, organic manure and bio-fertilizer play an important key role because they possesses many desirable soil properties and exerts beneficial effect on the soil physical, chemical and biological characteristics of the soil.

Its unique characteristics and adaptability to varied agro-climatic conditions and soils make soybean gain popularity worldwide. In Nagaland, the estimated area under soybean cultivation is 24860 hectares with a production of 31170 metric tons (Anonymous, 2017) and productivity of $1253.82 \mathrm{~kg} \mathrm{ha}^{-1}$. It is one of the most popular food items of majority of the people of Nagas.

It is utilized as a fermented product as well as pulse crop. In spite of its popularity in the states, the farmers give very little priority for its cultivation on large scale as a sole crop because the productivity is less due to the differences created in nutrient removal by the crop and the nutrient present in the soil leading to decline in soil fertility. The traditional practice of slash and burning of the jhum lands also leds to gradual decrease in the soil base contents and the soil becomes less fertile for crop production. The loss of nutrient due to run off and leaching caused by high rainfall in the region also increased the deterioration of soil health and fertility. Therefore, it was a felt need to restore the soil fertility and health with sustainability in crop production, thus this field experiment was undertaken with the following objectives:

Yield

Economics

Soil fertility before and after harvest

\section{Materials and Methods}

A field level demonstration on technology dissemination was carried out in three villages under zunheboto district of Nagaland viz., Zaphumi, Lumami and Aotsakili covering 3 ha of jhum lands. A total of 9 demonstrations were carried out during 2014-15.The technology used were 10 tons $\mathrm{ha}^{-1}$ of FYM combined with biofertilizer Rhizobium and phosphorus solubilizing bacteria (PSB). The demonstration fields were moderately acidic to acidic in reaction ranging from 6.0-6.4, low to medium organic $\mathrm{C}$ ranging from 0.27 $0.63 \%, 229-249 \mathrm{~kg} \mathrm{ha}^{-1}$ of low available $\mathrm{N}$, $8.89-15.21 \mathrm{~kg} \mathrm{ha}^{-1}$ of low available P (P2O5) and $167.23-227.81 \mathrm{~kg} \mathrm{ha}^{-1}$ Of low available $\mathrm{K}$ (K2O).

The soybean crop was sown during the kharif season on $18^{\text {th }}$ of june 2014 using soybean variety JS-335 and harvested on $20^{\text {th }}$ of oct 2014. Parameters such as yield, gross income, cost of cultivation, net income and $\mathrm{B}: \mathrm{C}$ ratio were recorded and comparison of the datas from the analysis were made between the farmers and recommended practice.

Soil fertility statuses of the plots were also recorded before and after harvest. The soil $\mathrm{pH}$, organic carbon, available nitrogen, available phosphorus and available potassium were analysed using $\mathrm{pH}$ meter (Jackson, 1973), Walkely and Black method (Jackson, 1973), alkaline KMnO4 distillation method (Subbiah and Asija, 1956), Bray's No. 1 method (Bray and Kurtz, 1945), flame photometer (Jackson, 1973). 


\section{Results and Discussion}

The results shown in table-1 revealed that the yield obtained from the demonstration plots were higher than the yield obtained from the traditional farmer's practice of zero application of nutrients in the soil. Application of 10 tons $\mathrm{ha}^{-1}$ of FYM along with biofertilizer rhizobium and PSB showed higher yield as compared to farmer's practice. The mean yields from the demonstration plots were $1218 \mathrm{~kg} \mathrm{ha}^{-1}$ as compared to the farmer's practice $\left(1013 \mathrm{~kg} \mathrm{ha}^{-1}\right)$. Datta et al., (2006) also observed increased in the yield of rajmash due to the use of rhizobium biofertilizer and fym and also found an increase in nitrogen accumulation in all stages of its growth over control.

The cost of cultivation was a little higher in the demonstrated plots as compared to farmer's practice due to the cost incurred in purchased of biofertilizer, organic manure and transportation. However the combined application of biofertilizer and fym fetched higher mean net return of Rs.35430and B:C ratio of 2.48 from the treated plots as compared to farmers practice. Kumar V.(2009) also reported significant higher seed yield, net return and B:C ratio with the combined application of FYM along with rhizobium and PSB in kharif soybean. The traditional method of cultivation through slash and burn leads to soil deterioration and poor soil health and fertility. Fixation of nutrient is also a great concern in the hilly region due to heavy rainfall (Saha et al., 2012). Thus application of biofertilizer in seed, root or soil helps in mobilization and availability of the nutrients in the soil, improving soil health and fertility and ultimately leads to sustainable production (Bhardwaj et al., 2014).

The mean soil available $\mathrm{N}, \mathrm{P}$ and $\mathrm{K}$ in the demonstration plot safter crop harvest was found to be increasedviz.,299, 88.67, 320.33 $\mathrm{kg} \mathrm{ha}^{-1}$ as compared to farmers practice (Table 2.). Similar observation was also made by Sharma V. (2013) with the application of fym and rhizobium in garden pea - buck wheat cropping sequence where soil fertility was restored through fym and rhizobium biofertilizer.

Biofertilizers plays a key role in not only improving the nutrient uptake by the crop but also helps in sustainable soil management through nutrient transformation, increase in organic matter content and maintaining soil $\mathrm{pH}$ due to release of various organic acids, thereby restoring soil fertility and soil health (Khanna et al., 2019).

Table.1 Effect of Biofertilizer and FYM on Yield and Economics of Soybean

\begin{tabular}{|c|c|c|c|c|c|c|c|c|c|c|c|}
\hline \multirow[t]{2}{*}{$\begin{array}{l}\text { Name } \\
\text { of the } \\
\text { village }\end{array}$} & \multirow[t]{2}{*}{$\begin{array}{c}\text { No. of } \\
\text { demonstrations }\end{array}$} & \multicolumn{2}{|c|}{$\underset{\left(\mathrm{kg} \mathrm{ha}^{-1}\right)}{\text { Yield }}$} & \multicolumn{2}{|c|}{$\begin{array}{c}\text { Cost of } \\
\text { cultivation } \\
(\text { Rs })\end{array}$} & \multicolumn{2}{|c|}{$\begin{array}{c}\text { Gross } \\
\text { income } \\
(\mathbf{R s})\end{array}$} & \multicolumn{2}{|c|}{$\begin{array}{c}\text { Net } \\
\text { income } \\
\text { (Rs) }\end{array}$} & \multicolumn{2}{|c|}{$\begin{array}{l}\text { B:C } \\
\text { ratio } \\
\text { (Rs) }\end{array}$} \\
\hline & & FP & DP & FP & DP & FP & DP & FP & DP & FP & DP \\
\hline Zaphumi & 3 & 1000 & 1200 & 18420 & 23500 & 42800 & 57250 & 23050 & 33750 & 2.32 & 2.44 \\
\hline Lumami & 3 & 1015 & 1220 & 17940 & 23910 & 42910 & 59430 & 24970 & 35520 & 2.39 & 2.49 \\
\hline Aotsakili & 3 & 1025 & 1235 & 18640 & 24500 & 43540 & 61520 & 25480 & 37020 & 2.41 & 2.51 \\
\hline Mean & & 1013 & 1218 & 18333 & 23970 & 43083 & 59400 & 24500 & 35430 & 2.37 & 2.48 \\
\hline
\end{tabular}

$\mathrm{FP}=$ Farmers Practice, $\mathrm{DP}=$ Demonstrated Plot, $\mathrm{B}: \mathrm{C}=$ Benefit $:$ Cost 
Table.2 Effect of Biofertilizer and FYM on Soil Fertility

\begin{tabular}{|l|c|c|c|c|c|c|}
\hline \multirow{2}{*}{$\begin{array}{l}\text { Name of the } \\
\text { village }\end{array}$} & \multicolumn{4}{|c|}{ Soil fertility status after harvest } \\
\cline { 2 - 7 } & Available N & \multicolumn{2}{|c|}{ Available P } & \multicolumn{2}{c|}{ Available K } \\
\cline { 2 - 7 } & FP & DP & FP & DP & FB & DP \\
\hline Zaphumi & 274 & 298 & 19 & 39 & 291 & 310 \\
\hline Lumami & 270 & 293 & 17 & 36 & 304 & 332 \\
\hline Aotsakili & 283 & 306 & 21 & 41 & 287 & 319 \\
\hline Mean & 275.67 & 299 & 19 & 88.67 & 294 & 320.33 \\
\hline
\end{tabular}

FP= Farmers Practice, DP= Demonstrated Plot

From the above front line demonstrations carried out in soybean under acidic upland soils of zunheboto district, it was found that the application of 10 tons of fym ha ${ }^{-1}$ along with biofertilizer rhizobium and PSB either through seed or soil treatment obtained higher seed yield, net return and $\mathrm{B}: \mathrm{C}$ ratio over traditional farmers practise. The available $\mathrm{N}$, $\mathrm{P}$ and $\mathrm{K}$ in soil after harvest was also found to be increased in demonstrated plot. From these observations, it was concluded that this technology can be adopted to improve the economic feasibility of the small and marginal farmers, increase the nutrient availability, restore the soil fertility and soil health in a sustainable manner in jhum fields. Therefore this technology can be taken up in a broad way among the farming communities to enhance the soil health and fertility in the jhum fields and ultimately leads to sustainable livelihood.

\section{References}

Anonymous (2013). All India Coordinated Research Project on Soybean, Annual Report.

Anonymous. (2017). Statistical Handbook of Nagaland. pp. 39.

Anonymous. (2019). USDA. World agricultural production.

Bhardwaj D., Ansari M.W., Sahoo R.K. and Tuteja N. (2014). Biofertilizers function as key player in sustainable agriculture by improving soil fertility, plant tolerance and crop productivity. Microb Cell Fact. Vol 13 (66).

Datta N., Rana, M.C. and Sharma, R.P. (2006). Effect of seed inoculation and farm yard manuring on nitrogen balance and yield in Rajmash (Phaseolus vulgaris). Indian Journal of Plant Physiology. vol. 11(1): 108-112.

Herliana, O., Harjoso, T., Anwar, A.H.S. and Fauzi, A. (2015). The effect of rhizobium and $\mathrm{n}$ fertilizer ongrowth and yield of black soybean (Glycine max L. Merril). Earth Environ. Sci. 255( 01).

Khanna R., Pawar, J., Gupta S., Verma H.,Trivedi, H.,Kumar, P. and Kumar, R. (2019). Efficiency of biofertilizers in increasing the production potential of cereals and pulses: A review. $J$ Pharmacogn Phytochem.Vol.8(2): 183188

Kumar V. (2009). Effect of organic manure and bio-fertilizer on growth, yield and quality of soybean [Glycine max (L.) merril].Agronomy Thesis, jau,Junagadh . Pages: 177.

Saha R., Chaudhary, R.S. and Somasundaram, J. (2012). soil management for sustainable agriculture. Appl Environ Soil Sci.Vol 9 .

Sharma V. (2013). Studies on integrated nutrient management inm in garden pea based cropping systems under dry temperate high hill conditions. Thesis, CSK Himachal Pradesh Agricultural University . 
Subba Rao, N. S. (1982) Bio-fertilizers in advances in agricultural microbiology.
Oxford \&IBH PUB, CO; NewDelhi. P. 219-242.

\section{How to cite this article:}

Sentimenla. 2020. Response of Soybean (Glycine max L. Merril) to Biofertilizer and FYM in the Jhum Fields under Zunheboto Districts of Nagaland, India. Int.J.Curr.Microbiol.App.Sci.

9(06): 126-130. doi: https://doi.org/10.20546/ijcmas.2020.906.016 